\title{
Ibrahimova R.Sh. \\ The effects of anthropogenic factors on the formation of helminth fauna of domestic carnivores in the territory of Azerbaijan
}

Azerbaijan National Academy of Sciences

(Azerbaijan, Baku)

doi 10.18411/gq-31-03-2021-13

idsp sciencerussia-31-03-2021-13

\section{Abstract}

As a result of long-term studies, it has been identified that the effects of anthropogenic factors on the formation of helminth fauna of domestic carnivores are reflected in a number of changes. Thus, primarily due to the change in habit of animal, the quantitative and qualitative changes have happened in the helminth fauna: new species of helminths which assume epizootic and epidemiological significance has been found and this has significantly enriched the species composition of the helminth fauna. Due to the influence of anthropogenic factors, the mixed parasitic focuses have formed and 14 species of helminths have included in helminth fauna. The domestic carnivores infected with pathogenic helminths from this focus infect human beings, domestic and ruminating animals from sinantropic focus. Thus, due to impact of the anthropogenic factors, the helminth fauna of animals has changed and has acquired its modern helminthological status.

Kew words: stray dog, domestic cat, helminth, fauna, anthropogenic factors, parasitic focus

\section{Introduction}

Some animals (especially the domestic and wild carnivores) are the major hosts of pathogenic helminths, as well as their carriers and transmitters in nature. There are a number of factors that directly affect the spread of pathogenic helminths among the animals and the formation of their helminth fauna. It has been established that in the modern era the most important one of these factors is the anthropogenic factors.

The influence of anthropogenic factors on the formation of helminth fauna of the domestic carnivores, as well as their species composition has not yet been studied. The influence of anthropogenic factors on the formation of helminth fauna of fox, jackal which belong to wild carnivores have only been very partially studied (1).

Due to the effects of anthropogenic factors, primarily the habit of animals is subject to change. As a result, the species composition of helminth fauna includes the dangerous helminths assuming epizootic and epidemiological significance. Domestic carnivores also infect the human and domestic ruminating animals from sinantropic focus with pathogenic helminths included in their helmint fauna (2).

The study of the effects of anthropogenic factors on the formation of the helminth fauna of the domestic carnivores and the increase in its species diversity is a current issue of our era and suggests the practical significance.

It is therefore useful to study the effects of anthropogenic factors affecting the formation of the helminth fauna of the domestic carnivores in Azerbaijan.

\section{Material and methods}

For this purpose, we have studied 756 stray dogs and 973 domestic cats from various areas of Azerbaijan by applying hematological dissection (3). The cestodes from the found helminths were fixed in $70^{\circ}$ alcohol, while nematodes in $4 \%$ formalin. In the identification of cestodes, permanent medicines are made using the coloring method. Temporary medicines are made from nematodes by mixing milk acid with glycerin (1:1). Either permanent or temporary medicines and biometric meas3urements have been specified in the dimension of MBI-6, x20 and x40 based on specification book by using the Olympus microscope for each type. 


\section{Result and discussions}

As a result of our research 62 species of helminths were found in the domestic carnivores. 7 species of these helminths are trematod, 26 species are cestodes, 1 species is acantosephal and 28 species belong to the nemathelminths. According to life cycles of helminths, 51 species of helminths are biohelminth, while 11 species are geohelminth (Table $1)$.

Table 1

Helminths of domestic carnivores in territory of Azerbaijan

\begin{tabular}{|c|c|c|}
\hline $\begin{array}{ll}\text { Helminth types } & \text { Animals } \\
\end{array}$ & Stray dogs & $\begin{array}{c}\text { Felis } \\
\text { domestica }\end{array}$ \\
\hline \multicolumn{3}{|l|}{ Trematodes } \\
\hline Alaria alata Goeze & + & + \\
\hline Plagiorchis elegans Rudolphi & + & + \\
\hline Euparyphium melis Schrank & + & _- \\
\hline Echinochasmus perfoliatus Ratz & + & + \\
\hline Cryptocotyle lingua Creplin & + & + \\
\hline Pharhyngostomum cordatum Diesing & + & + \\
\hline Ph. fausti Skrjabin et Popov & & + \\
\hline \multicolumn{3}{|l|}{ Cestodes } \\
\hline Diphyllobothrium latum Lühe & _- & + \\
\hline Spirometra erinacei-europei Rudolphi & + & + \\
\hline Dipylidium caninum Lühe & + & + \\
\hline Diplopylidium nolleri Skrjabin & + & + \\
\hline D. skrjabini Popov & & + \\
\hline Joyeuxiella echinorhynchoides Sonsino & + & + \\
\hline J.rossicum Skrjabin & - & + \\
\hline J.pasgualei Diamare & + & + \\
\hline Taenia hydatigena Pallas & + & + \\
\hline T.solium (larvae) Linnaeus & _ & + \\
\hline T. crassiceps Zeder & + & + \\
\hline T.laticollis Rudolphi & + & + \\
\hline T.parenchimatosa Pushmenkov & + & _- \\
\hline T. ovis Cobbold & + & - \\
\hline T. cervi Christiansen & + & _- \\
\hline T.krabbei Moniez & + & _. \\
\hline T.pisiformis Bloch & + & + \\
\hline Hydatigera taeniaeformis Batsch & + & + \\
\hline H.krepkogorski Schulz et Landa & + & + \\
\hline Multiceps multiceps Leske & + & _- \\
\hline Alveococcus multilocularis Leuckart & + & _- \\
\hline Echinococcus granulosus Batsch & + & - \\
\hline Tetratirotaenia polyacantha Leuckart & + & - \\
\hline Mesocestoides lineatus Goeze & + & + \\
\hline M. corti Hoeppli & + & - \\
\hline M.petrowi Sadychov & + & - \\
\hline \multicolumn{3}{|l|}{ Akantosefala } \\
\hline \multirow{2}{*}{\multicolumn{3}{|c|}{ Nematodes }} \\
\hline & & \\
\hline Capillaria plica Rudolphi & + & + \\
\hline C.felis-cati Bellingham & - & + \\
\hline C. putorii Rudolphi & + & + \\
\hline Thominx aerophilus Creplin & + & + \\
\hline Trichocephalus georgicus Rodonaya & + & _ \\
\hline Tr. vulpis Froelich & + & - \\
\hline Trichinella spiralis Owen & + & + \\
\hline Strongyloides vulpis Petrow & + & _- \\
\hline Ancylostoma caninum Ercolani & + & + \\
\hline A.tubaeforme Zeder & & + \\
\hline
\end{tabular}




\begin{tabular}{|l|c|c|}
\hline Uncinaria stenocephala Railliet & + & + \\
\hline Gongylonema pulchrum Molin & + & - \\
\hline Grenosoma vulpis Rudolphi & + & + \\
\hline Troglostrongylus brevior Gerichter & + & - \\
\hline Angiostrongylus vasorum Railliet & + & + \\
\hline Molineus patens Dujardin & + & + \\
\hline Toxascaris leonina Linstow & + & + \\
\hline Toxocara canis Werner & + & + \\
\hline T. mystax Zeder & + & - \\
\hline Spirura rytipleurites Deslongchamps & + & - \\
\hline Spirocerca arctica Petrow & + & + \\
\hline Sp.lupi Rudolphi & + & + \\
\hline Physaloptera praeputiale Linstow & + & + \\
\hline Ph. sibirica Petrow et Gorbunow & + & + \\
\hline Rictularia affinis Jagerskiold & + & \\
\hline R.cahirensis Jagerskiold & + & + \\
\hline Ascarops strongylina Rudolphi & + & + \\
\hline Dirofilaria repens Railliet et Henry & + & $\mathbf{4 1}$ \\
\hline Total: 62 & $\mathbf{5 5}$ & \\
\hline
\end{tabular}

The effects of anthropogenic factors in the territory of the Republic (deforestation, laying of new oil, gas and water pipes, expansion of individual planting-soil fields) has caused the narrowing of natural feeding areas of wildlife. On the other hand, the prohibition of hunting of wild animals and the stooping of leather supply in order to protect the biodiversity of animals have led to a significant increase in the number of wild animals. This has resulted in increased wildlife density in nature and lack of food among animals.

These factors have led to regularly moving of wild animals from natural feeding areas to the sinantropic focus - dwellings to get a food. As such cases last a long period of time, the mixed focus has formed between the natural focus and sinantropic focus.

This mixed focus is always polluted with helminth eggs, where the mutual invasion occurs between wild and domestic carnivores. This means that in the mixed focus the domestic carnivores are infected with helminths that are inherent in wild carnivores and in turn the wild carnivores are infected with helminths belong to domestic carnivores. The infected animals also spread the eggs of the infected dangerous helminths in sinantropic focus and infect human and domestic ruminating animals by seriously damaging them from the medical, veterinary and sanitary point of view $(4,5)$.

The transmission of pathogenic helminths from natural focus to sinantropic focus and vice versa leads to the formation of helminth fauna in both focus.

The impact of anthropogenic factors is reflected in this scheme:

anthropogenic factors $\rightarrow$ parasitic mixed focus $\rightarrow$ domestic carnivores $\rightarrow$ infection of humans and domestic animals.

During the long-term studies (1999-2015), it was established that domestic carnivores were infected with 14 species of helminths which are inherent in wild animals (T.parenchimatosa, T.cervi, T.krabbei, T.laticollis, T.polyacantha, M.corti, G.pulchrum, T.brevior, A.strongylina, M.patens, T.vulpis, S.vulpis, A.vasorum, S.lupi) and we have considered the domestic carnivores as new hosts for these helminths (2).

As a result of the anthropogenic factors, the species assuming epizootic and epidemiological significance (Gongylonema pulchrum, Mesocestoides corti, T.cervi, T. krabbei, T. polyacantha, T.vulpis, S.vulpis) have included in the newly formed helminth fauna of the domestic carnivores (4).

The changes resulting from anthropogenic transformation of landscape - deforestation, the expansion of planting-soil fields have led to a change in the habit of rodents (forest, field and other species of mice) which are the intermediate hosts of some cestodes and nematodes assuming epizootic and epidemiological significance. Thus, this has also resulted in change in 
the permanent habitats, the number dynamics, as well as the fauna of the intermediate hosts themselves.

So, due to the deforestation and the expansion of the planting-soil fields, rodents have also moved to different directions by changing their permanent locations. In the places they go, they infect other animals by spreading the helminth eggs and they themselves are infected with other species of helminths which are inherent in new environment. Other animals feeding with these infected rodents are infected with new species of helminths (6).

Since such cases last a long time, the helminth fauna with a new species composition of domestic carnivores has formed and has acquired its modern status.

Thus, the analysis of the results obtained from the carried out studies has found that the anthropogenic factors are primarily affect the formation of helminth fauna, the formation of parasitic focuses, the increasing number of pathogen helminthes assuming epizootic and epidemiological significance which include into composition of the helminth fauna and, ultimately, infection of humans and domestic animals with parasitic diseases. Therefore, the anthropogenic factors that adversely affect the formation of the helminth fauna of animals should be more clearly defined and should always be the focus of attention.

$$
* * *
$$

1. Fataliyev G.G., IbrahimovaR.Sh. Current state of helmint fauna of canidae in Azerbaijan. News of Azerbaijan National Academy of Sciences, Journal of Biology and Medical Sciences, N 1, 2015, 35-38 p.

2. IbrahimovaR.Sh. Plathways of Helminth Fauna Formation in Domestic Carnivores in Azerbaijan. Russian Journal of Biological Invasions, 2018, vol 9, № 1, pp. 46-49.

3. Skryabin K.I. Methods of full helmintological dissection of vertebrae, as well as human. M., 1928, Publication of Moscow State University, p 45.

4. IbrahimovaR.Sh. Factors that generate the variety of helminths of wild animals in the Lankaran natural region, their epizootic and epidemiological characteristics. Articles of Institute of Zoology of Azerbaijan National Academy of Sciences, Baku, 2015, Volume 33, N 1, 61-69p.

5. Karagezova A.A., Salekhov A.A., Mamedova G.M. Seroepidemiological characteristics of mixed foci of zoohelminthiasis (fascioliasis and unicameral echinococcosis). Health magazine Baku, 1995, c.76-77.

6. Aslanova E.K. The distribution of the helminth fauna of forest mammal on landscapes in the plain zone of the Lankaran natural region. Articles of Institute of Zoology of Azerbaijan National Academy of Sciences S. Dedicated to the 80th anniversary of the Institute of Zoology. Volume 34, N1, Baku, 2016 , p. $12-19$

\section{Manukyan I.R., Dogusova N.N. \\ Resistance of winter wheat cultivars to leaf rust in conditions of the Central Caucasus \\ North Caucasus Research Institute of Mountain and Foothill Agriculture - the branch of the Vladikavkaz Scientific Center of the Russian Academy of Sciences}

doi 10.18411/gq-31-03-2021-14

(Russia, Nalchik)

idsp sciencerussia-31-03-2021-14

\section{Abstract}

The main problem of wheat immunity to leaf rust is the loss of efficiency of most $L r$ genes. The decrease in efficiency is associated with microevolutionary processes within the population and the emergence of new virulent phytopathogen races that can overcome previously efficient resistance genes. The article presents the results of the phytopathological test and marker analysis of the selected material of winter wheat for resistance to the leaf rust pathogen (Puccinia recondita Rob.ex Desm $f$. sp. tritici.). The object of the research was 20 cultivar samples of various ecological and geographical origins. DNA was isolated from the leaves of 10-day-old wheat germs. Molecular markers were used for the following genes: $\operatorname{Lr} 9$ (SCS5), Lr10 (Fi.2245/Lr10-6/r2), Lr19/Sr25 (SCS265), Lr20/Sr15 (STS638), Lr24/Sr24 (Sr24\#12), Lr34/Sr57 (csLV34), Lr37/Sr38/Yr17/Pch2/Cre5 (Ventriup/LN2), Lr41 (GDM35), Lr47 (PS10). Using molecular markers, the studied wheat varieties did not reveal the highly 